\title{
Ultrastructural observations of the larva of Tubiluchus corallicola (Priapulida)
}

\author{
R. P. Higgins ${ }^{1} \&$ V. Storch ${ }^{2}$ \\ ${ }^{1}$ Department of Invertebrate Zoology, National Museum of Natural History, Smithsonian \\ Institution; Washington, D.C. 20560, USA \\ ${ }^{2}$ Zoologisches Institut der Universität; Im Neuenheimer Feld 230, D-6900 Heidelberg, \\ Federal Republic of Germany
}

\begin{abstract}
Larvae of Tubiluchus corallicola van der Land 1968 were investigated by scanning and transmission electron microscopy. The scalids are sensory organs, each has a bipolar receptor cell with a single apical cilium similar to the scalids in the adult. Muscle cells of the larva are more differentiated than previously reported for other Priapulida; the larval arrangement of circular and longitudinal musculature differs from that of the adult, and a diaphragm is reported for the first time in Priapulida. The diaphragm may function in hydrostatic control of eversion and inversion of the introvert and mouth cone. The functional morphology of these two structures is discussed and contrasted with the Kinorhyncha.
\end{abstract}

\section{INTRODUCTION}

All known larvae of Priapulida are remarkably uniform when compared with the morphological variation observed in adults (Hammarsten, 1915; van der Land, 1970; Lang, 1948; Purasjoki, 1944). The body of the larval stages consists of abdomen (trunk), neck, and introvert. The latter two can be withdrawn into the abdomen, which is surrounded by a lorica, i.e., a relatively rigid cuticle with longitudinal ridges. The terminal mouth cone of the spherical introvert has several rings of teeth which are anteriorly directed when both introvert and mouth cone are everted. The remaining part of the introvert bears several rings of scalids. The latter along with the teeth exhibit little differentiation among the genera.

According to van der Land (1975), three types of larvae can be distinguished at present: (1) In Tubiluchus the lorica is round in cross section and supplied with 20 equally spaced longitudinal ridges of which 10 are more pronounced (primary ridges) and alternate with less distinct secondary ridges (Kirsteuer, 1976). Up to about 20 tubuli are placed on the primary ridges; (2) in Priapulus, Priapulopsis, and Maccabeus the lorica is dorsoventrally flattened, provided with eight longitudinal ridges along its lateral sides, and 4 or 8 (Maccabeus) tubuli; (3) in Halicryptus there are also 8 lateral ridges but tubuli are lacking and the dorsal and ventral fields are more heavily cuticularized and provided with an areolate sculpture. The only transmission electron microscopic data available on the larvae of Priapulida was given by Moritz (1972). According to this author, the introvert of the larva of Halicryptus spinulosus bears a two-layered cuticle similar to that 
of the adult. The abdomen has a completely different cuticle consisting of three layers, the innermost of which bears many pore canals running more or less in parallel. In some areas they anastomose.

\section{MATERIAL AND METHODS}

Larvae of Tubiluchus corallicola van der Land were collected in Castle Harbor, Bermuda in June 1987 and transported live to a laboratory at the nearby Bermuda Biological Station. For this investigation we used larvae of 200 and $300 \mu \mathrm{m}$ in length (in Araldite), which according to Kirsteuer (1976) means that larval stages 2 and 3 were used. The specimens were immersed in ice-cold glutaraldehyde $(3.5 \%$ in Sörensen phosphate buffer at $\mathrm{pH}$ 7.5). After postfixation in $\mathrm{OsO}_{4}$, the specimens were dehydrated in ethanol and embedded in Araldite. For light microscopy, serial sections were used. Thin sections were stained for $5 \mathrm{~min}$ with uranyl acetate (saturated solution $70 \%$ methanol) and for another $5 \mathrm{~min}$ in lead citrate. The sections were examined under a Zeiss EM 9S2 (TEM) and a Zeiss EM 10C (TEM) electron microscope. For scanning electron microscopy (SEM), specimens were critical-point dried, coated with gold and examined with a Cambridge SEM S 4-10 microscope.

\section{RESULTS}

The scanning micrographs presented in Figure 1 give a general impression of the external morphology of a larva of Tubiluchus corallicola when neck and introvert, including its mouth cone, are everted. Figure 2 shows, in a schematic line drawing, an idealized longitudinal section through a larva with its neck and introvert withdrawn into the abdomen.

In the abdomen, the ultrastructure of the cuticle consists of an electron-dense distal layer and a fine fibrillar electron-lucent proximal zone (Fig. 3a). The cuticle is underlain by flat epidermal cells the lateral plasma membranes of which are heavily interdigitated. In their cytoplasm, large electron-dense inclusions are the most prominent structures. The nuclei, too, are flattened.

There are ten very prominent cuticular ridges (the primary ridges), which are composed of cuticular material only. Gland cells can be found near the tubuli. They resemble the corresponding structures in adults (Storch \& Alberti, 1985). The ventral nerve cord, consisting of about 100 fibres, is located in the epidermis; additionally smaller bundles of intraepidermal nerve cell processes were found.

The epidermis is subtended by a layer of circularly arranged muscle cells with single long mitochondria and another layer of longitudinal muscle cells (Fig. 3a). The latter is not continuous, its cells may be deeply embedded in the circular muscle cells, or longitudinal cells may accommodate circular muscle cells in invaginations of their cell membrane. The musculature lies adjacent to the general body cavity which is only a small cleft in these animals.

The transitory opening into the anterior region of the inverted and withdrawn mouth cone is surrounded by a hood of the body wall, the centre of which consists of an extremely thin body cavity (Fig. 3b).

The mouth cone armature consists of rings of teeth (Fig. 1b-d) which were investigated by SEM (Kirsteuer, 1976). The cuticle of these teeth has a thickened electron-dense layer at their anterior face (Fig. 4a). The underlying cells possess only a few mitochondria, 

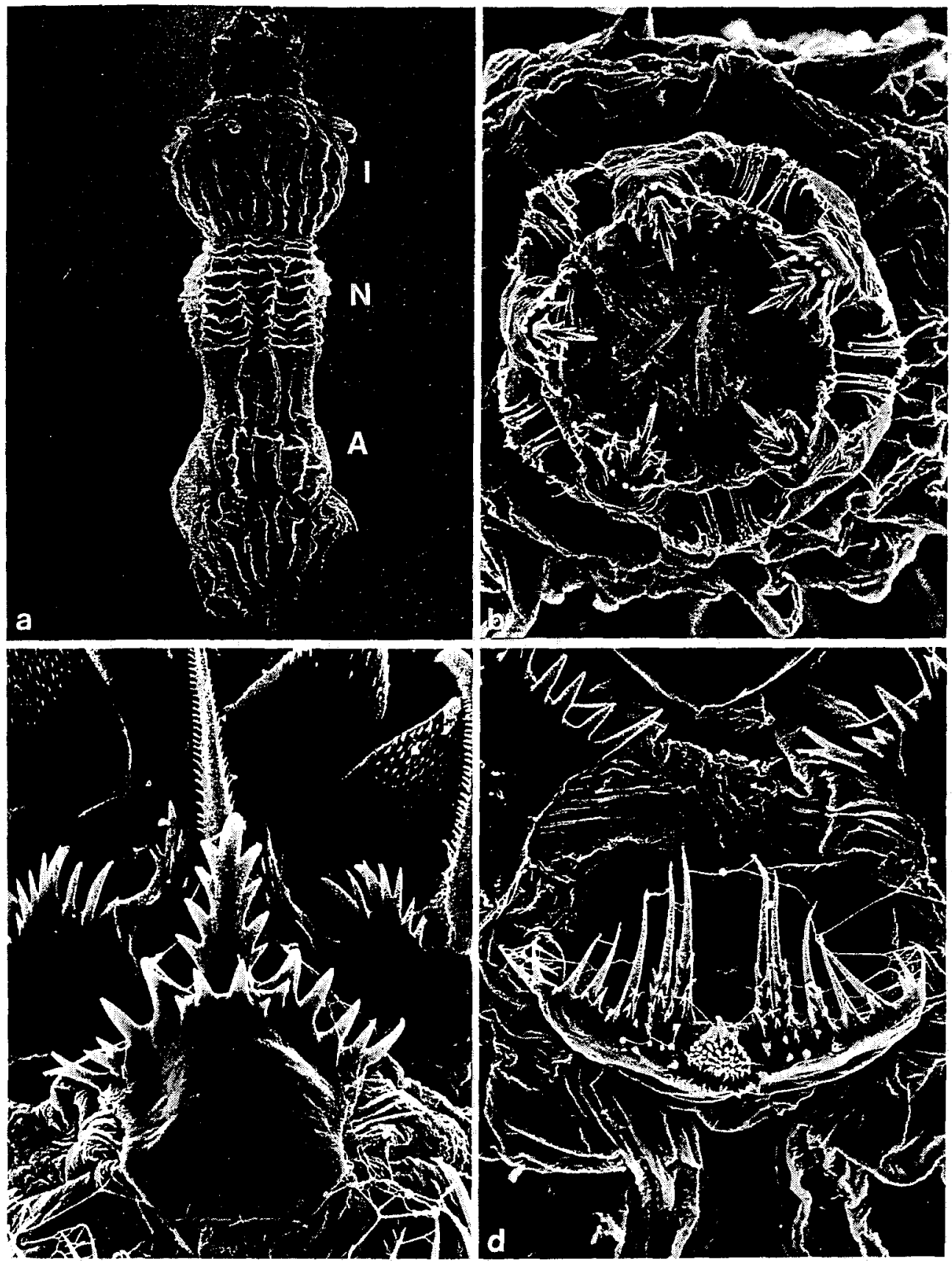

Fig. 1. Scanning electron micrographs of a larva of Tubiluchus corallicola. a: Larva with everted neck (N) and introvert $(\mathrm{I})$; $\mathrm{A}=$ abdomen $(170: 1)$; b: Mouth cone with teeth $(750: 1)$; $\mathrm{c}$, d: different teeth of the mouth cone $(2000: 1)$ 


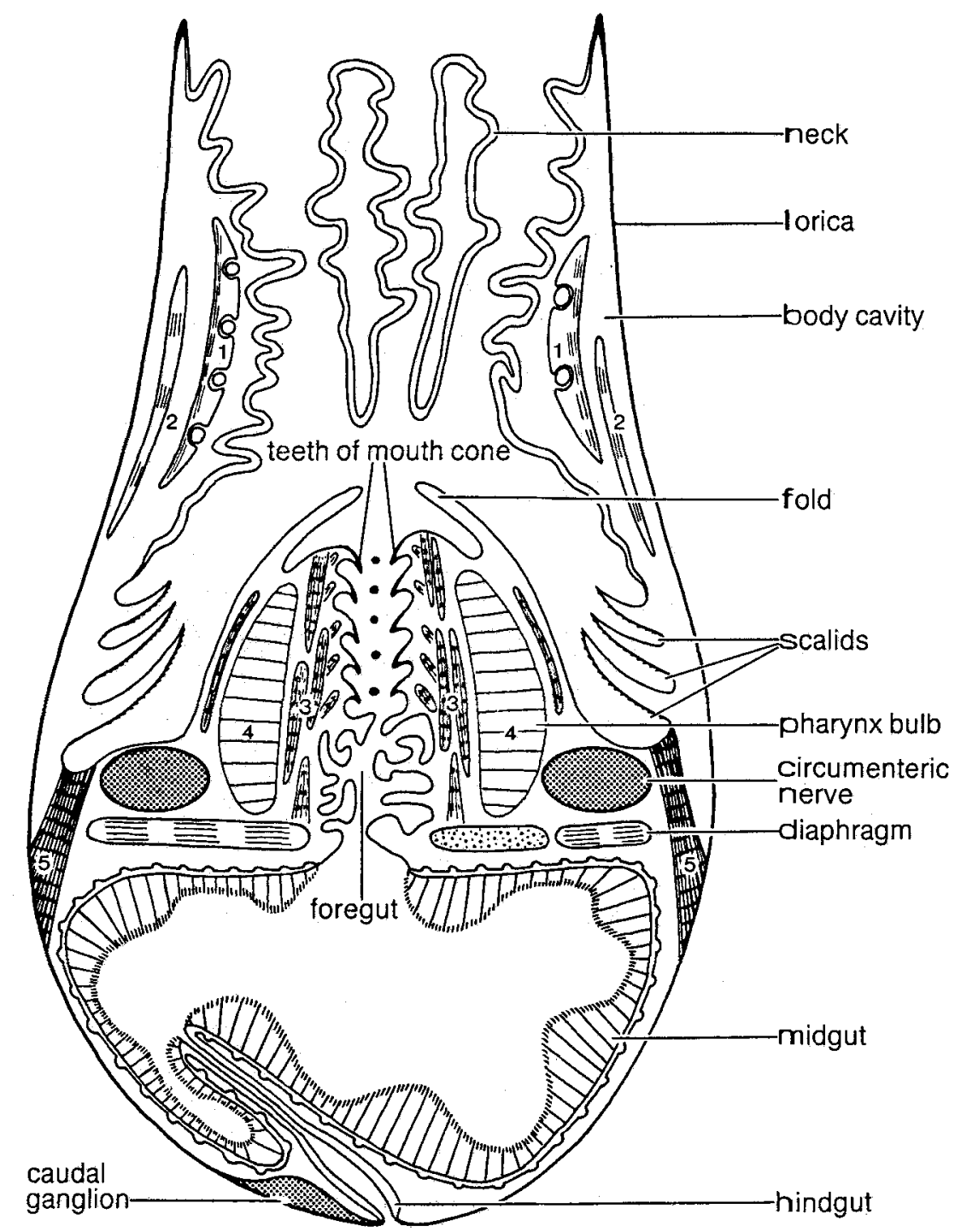

Fig. 2. Schematic drawing of larva with neck and introvert withdrawn into abdomen; 1-5: different kinds of muscle cells. 1: longitudinal muscle cell with circular muscle cells embedded in it; 2 : muscle cell with one or two fibrils (cf. Fig. $6 a, b) ; 3$ : muscle cells within pharynx bulb (cf. Fig. 4c); 4: pharynx bulb (cf. Fig. 4d); 5: retractor muscle cell (cf. Fig. 6c, d)

cisternae of rough endoplasmic reticulum and electron-dense bodies of unknown nature. Often, centrioles were found in an apical or subapical position. The nuclei are round. Some epithelial cells are differentiated into tendon cells, e.g. they are dominated by bundles of tonofilaments.

Surrounding the teeth of the withdrawn mouth cone and the foregut is a very strong and well circumscribed muscle layer composed of regularly arranged cells the filaments 


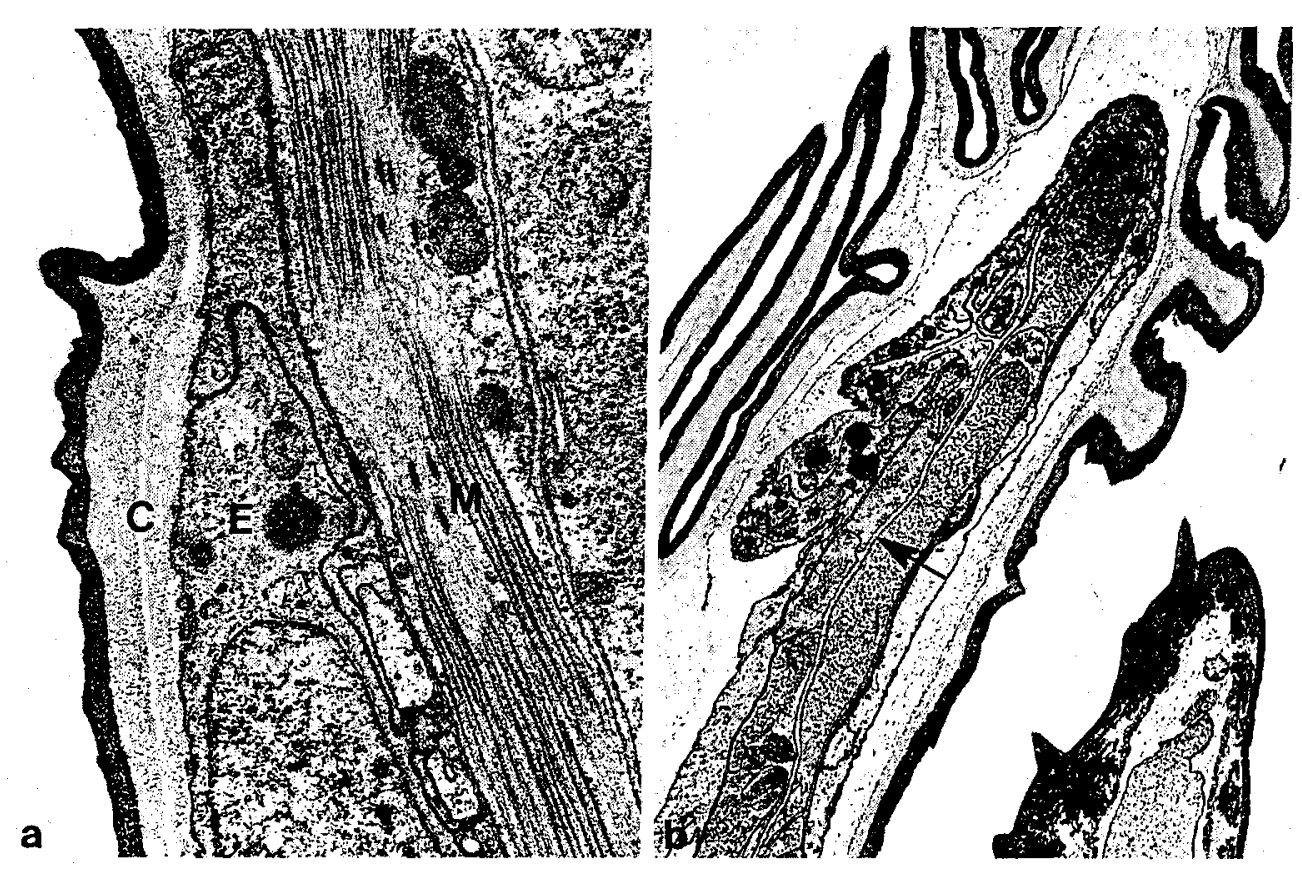

Fig. 3a. Integument of the trunk $(13200: 1)$. C: cuticle, E: epidermis, M: muscle cell; b: hood, with extremely narrow body cavity (arrow), surrounding the mouth cone $(7100: 1)$

of which run preferentially in a circular manner (Figs 2,4d). However, within one cell the orientation of the filaments varies considerably. Inside and outside of this pharynx bulb longitudinal muscle strands occur (Fig. 2).

Following the pharynx bulb is an irregularly shaped section of the foregut with an extremely thin and electron-lucent cuticle (Figs 2, 4b).

Scalids have been studied with SEM by a number of authors (Kirsteuer \& Rützler, 1973; Calloway, 1975; Kirsteuer, 1976). The cuticle covering the scalids possesses many spines anteriorly (Fig. 5a), but presents an ultrastructure similar to that of the neck posteriorly. In some areas, the electron-lucent layer of the cuticle bears an additional dark layer. The scalids are sensory organs as in adults. They consist of bipolar receptor cells each with a single apical cilium (Fig. 5a) which penetrates deeply into the cuticle (Fig. 5b, inset) where it eventually ends near a distal opening.

The cuticle of the neck forms many ridges (Fig. 2). When the introvert and neck are withdrawn, this cuticle is thicker than the cuticle of the lorica. The underlying epithelial cells are irregular in shape, they may be cylindrical to flat, their nuclei are often round, and electron-dense bodies often occur. The epidermis is subtended by strands of circular muscle cells, which do not form a continuous layer. Often they are embedded deeply in the epidermis. The adjacent layer of longitudinal muscle cells is composed of two celltypes: cross-striated muscle cells with dominating fibrillar material and single "empty" cells with only a small amount of contractile material (Fig.6a, b) and which insert immediately behind the scalids. They may have one or, more often, two myofibrils. 


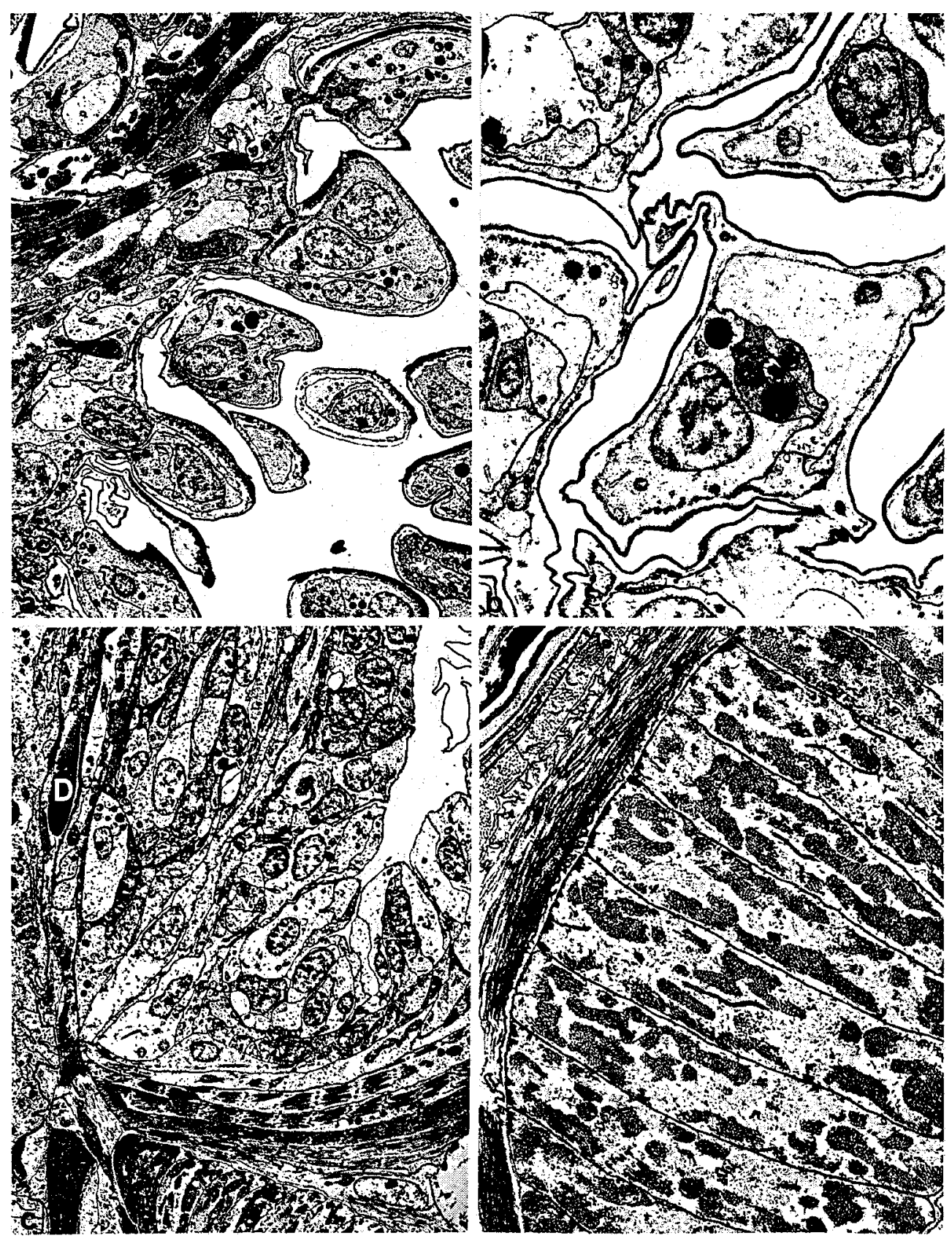

Fig. 4. Mouth cone and anterior part of alimentary canal. a: Longitudinal section of mouth cone with teeth and retractor muscle cells $(2800: 1)$; b: Foregut with very irregular cuticle $(7100: 1)$; c: Diaphragm (D) and foregut with pharyngeal bulb $(2700: 1)$; d: Pharyngeal muscle bulb (7100:1) 


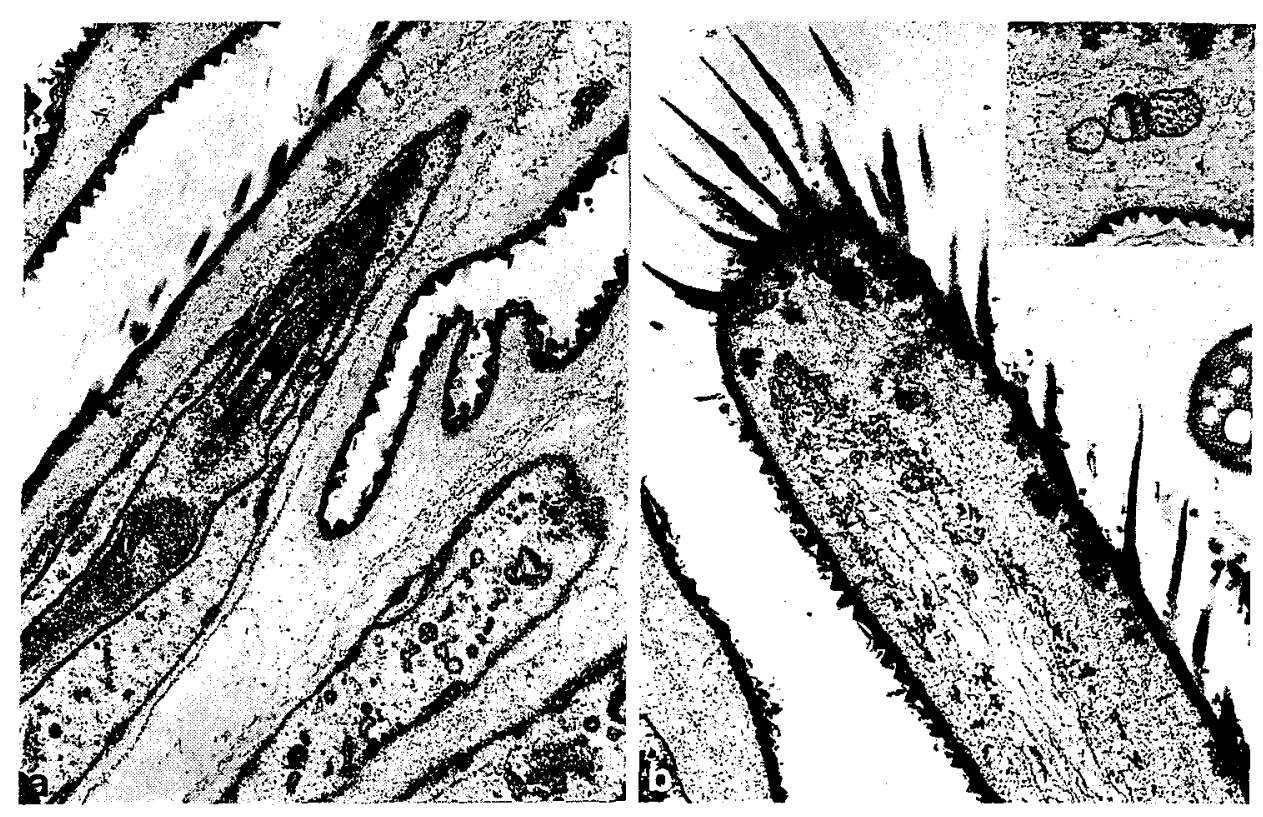

Fig. 5. Scalids. a: Section through proximal portion with dendrite and cilium at its distal tip (13250:1); b: Section through apical portion (13250:1). Inset: Cross section with cilia $(13250: 1)$

The ring nerve is located near the circular musculature of the pharynx and in the epidermis of the anterior portion of the introvert as in adults. The epidermis cells of this area contain centrioles which are arranged in couples. The cuticle forms an apodeme which suspends the nerve ring. The perikarya of the neurons are mainly in an anterior position. Single muscle cells lie immediately on the circumenteric nerve ring; however, in some parts the nervous tissue is located immediately at the body cavity. Additionally, there are a ventral nerve cord and a caudal or anal ganglion in the vicinity of the rectum (Fig. 2).

The dominating features of the body cavity are very thick retractor muscle cells. They connect the posterior portion of the abdomen with the introvert (Fig. 2) and contain many muscle fibrils (Fig.6c, d). These muscle cells have to undergo considerable length changes. They resemble the retractor muscle cells described by Candia Carnevalli \& Ferraguti (1979) for Halicryptus spinulosus. The body cavity contains amebocytes, irregular in shape, with globular cell nuclei, and numerous electron-dense inclusions. Sometimes, Golgi fields and centrioles could be seen in these cells. Mature erythrocytes were never found; developmental stages, however, are not rare. They are characterized by centrioles. The body cavity is divided into an anterior and a posterior chamber. Both compartments are separated by a strong muscular diaphragm. Anterior to the latter is the foregut and posterior the spacious midgut, the hindgut, and the protonephridia (the latter are not shown in Fig. 2 which represents a midsagittal section).

The protonephridia are composed of terminal cells with two cilia each. They resemble the protonephridia of adults (Alberti \& Storch, 1986). 

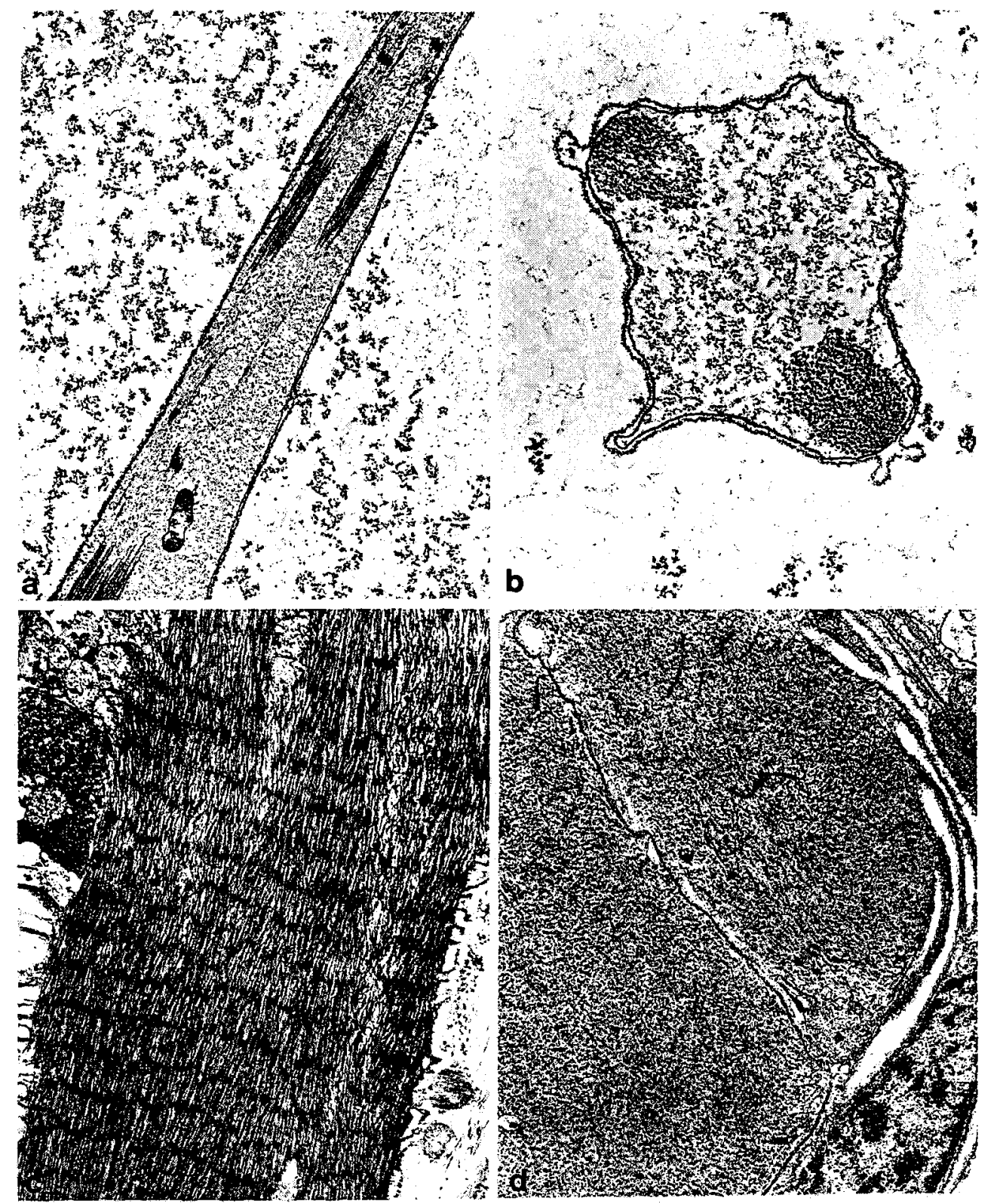

Fig. 6. Muscle cells. a, b: Muscle cells with few muscle fibrils. a: Longitudinal section (7000: 1); b: Cross section $(13000: 1)$; c, d: Muscle cells full of contractile material; c: Longitudinal section $(7000: 1)$; : Cross section $(13000: 1)$

The midgut may lie in the direct neighbourhood of the body wall musculature. Its epithelium is composed of only one cell type with apical microvilli. The lateral cell membranes of these cells are heavily interdigitated and characterized by many junctions. 
Their cytoplasm contains many electron-dense bodies and glycogen particles. Sometimes, lipid droplets were observed. The musculature is composed of an inner ring layer and longitudinal muscle cells. These two layers are not continuous. The hindgut has a very irregular cuticle with many ridges. The underlying epithelium contains many electron-dense granules. The epithelium is subtended by a one-layered ring musculature and a layer of longitudinal muscle cells.

\section{DISCUSSION}

Much attention has been given to the musculature of the Priapulida but most authors have described this system in gross anatomical terms only (see van der Land, 1970 and Hammond, 1970 for references). Electron microscopy has been applied by Mattisson et al. (1974), Candia Carnevalli \& Ferraguti (1979) and Storch et al. (in press). All but the most recent studies have concentrated on the adult musculature of the larger priapulids, namely Priapulus and Halicryptus. Our current study has revealed muscle cells of the larva of the meiofaunal priapulid Tubiluchus corallicola as far more differentiated than that reported for other Priapulida. In Halicryptus spinulosus the introvert retractors are similar to the retractor muscles in Tubiluchus larvae, but the latter has more muscle cell types. For example, some muscle cells of this larva have only a few myofibrils. Tubiluchus larvae also have obliquely and cross-striated muscle cells and their pharyngeal musculature is similar to that of other invertebrates having a pharyngeal bulb. Another larval feature is the inclusion of one muscle cell within another. The presence of a diaphragm muscle in the larvae is unique within the Priapulida. And finally, a mass of muscle cells is present inside and outside the pharynx bulb. Although its precise role is not clear, it is safe to assume that it functions in the operation and support of the mouth cone and its series of teeth. However, we also would point out that this complex of muscle cells (including the pharynx bulb) lies in the same position as the recently described coelomic chambers in Meiopriapulus fijiensis adults (Storch et al., in press). In the case of the latter these coelomic chambers appear to provide a hydroskeleton which produces radial force necessary for the pectinate teeth of Meiopriapulus to scrape off bacteria from the surrounding coarse sand particles and convey this food into the alimentary canal. In the case of the larva of Tubiluchus, its strongly cuspidate teeth suggest a mode of feeding wherein an anteriorly directed thrust is likely to be necessary.

The complexity of the larval musculature is as difficult to understand as is the combined action of muscle contraction and hydroskeletal procedure to operate the mouth cone of the larva. The latter is a poorly understood structure. Unlike the mouth cone of the Kinorhyncha which is protruded from the anterior region of the everted spherical head, the mouth cone of Tubiluchus adults and larvae merges from the same region by an eversion of the mouth cone as a continuous unfolding of a double layer of the mouth cone wall. The process allows the teeth which are posteriorly directed within the transitory mouth cone chamber (Fig. 2) to travel anteriorly until each ring of teeth passes over the anteriormost circumference of the mouth cone and becomes anteriorly directed (Fig. 1). Successive rings of teeth emerge from the mouth cone until the posteriormost (closest to the midgut) ring of teeth is extended and the anteriormost relevant to the fully everted mouth cone. What constitutes the mouth? If food enters the alimentary canal only when the mouth cone is inverted back into the introvert, one could assume that the mouth is 
that level of the foregut lumen adjacent to the posteriormost (nearest the midgut) row of the teeth. The mouth cone of the Priapulida neither functions as or is structurally similar to the mouth cone of the Kinorhyncha. In this latter phylum, the mouth cone is merely withdrawn into the introvert. In Kinorhyncha, the mouth is surrounded by a series of nine extremely positioned oral styles (the ventral style is absent) and occasionally secondary mouth cone styles are located posterior to the oral styles. Within the kinorhynch pharynx are three rings of pharyngeal styles. These may move slightly anteriorly, possibly by an eversion process during the kinorhynch's feeding activity, which is even less understood than that of the priapulid. The anteriormost ring of ten ( 2 alternating rows of 5 each) anteriorly directed pharyngeal styles tend to oppose the oral styles. The pharyngeal styles may be tooth-like in Paracentrophyes (Higgins, 1983) or more spinose as in Pycnophyes. The more weakly developed rings of five pharyngeal styles also are anteriorly directed within the pharyngeal lumen. This brings us to the role of another newly described muscle of the Tubiluchus larva, the diaphragm. We can only postulate that it functions to control the transfer of body cavity fluid as the introvert and mouth cone are moved in and out of the loricate trunk and neck region, and to maintain proper hydrostatic pressure in the everted head and mouth cone. Changes of hydrostatic pressure during eversion and inversion of the mouth cone can be accommodated by the elasticity and greater volume of the introvert itself, but when the latter, along with the mouth cone, is inverted and withdrawn into the lorica, the body fluid must be transferred posteriorly and probably is controlled, at least in part, by the diaphragm. In the adult, the musculature of the well developed body wall obviates the necessity of a diaphragm, since the former is capable of controlling the hydrostatic pressure supporting the everted introvert and mouth cone.

The nervous system of the Tubiluchus larva is similar to that of the adult (Rehkämper et al., in press); a circumenteric nerve ring with a ventral nerve cord leading to a caudal ganglion. The entire system is closely associated with the epidermal tissue. Bipolar sensory cells are present in the scalids as in scalids of Meiopriapulus, the sensory/ locomotory scalids of Kinorhyncha, but not the spines on the proboscis of Acanthocephala. The condition of the sensory (and locomotory?) scalids of the Loricifera has not yet been determined. Protonephridia, midgut, and hindgut are, in principle, similar to those of the adult (Alberti \& Storch, 1986; Storch \& Alberti, 1985).

Acknowledgements. This research was made possible by a NATO Grant for Collaborative Research. We are grateful for the technical assistance in electron microscopy provided by Miss R. Mummert and the use of laboratory facilities at the Bermuda Biological Station (Contribution No. 1191).

\section{LITERATURE CITED}

Alberti, G. \& Storch, V., 1986. Zur Ultrastruktur der Protonephridien von Tubiluchus philippinensis (Tubiluchidae, Priapulida). - Zool. Anz. 217, 259-271.

Calloway, C. B., 1975. Morphology of the introvert and associated structures of the Priapulid Tubiluchus corallicola from Bermuda. - Mar. Biol. 31, 161-174.

Candia Carnevalli, M. D. \& Ferraguti, M., 1979. Structure and ultrastructure of muscles in the Priapulid Halicryptus spinulosus: functional and phylogenetic remarks. - J. mar. biol. Ass. U.K. $59,737-744$.

Hammond, R. A., 1970. The burrowing of Priapulus caudatus. - J. Zool., Lond. 162, 469-480. 
Hammarsten, O. D., 1915. Zur Entwicklungsgeschichte von Halicryptus spinulosus (von Siebold). Z. wiss. Zool. 112, 527-571.

Higgins, R. P., 1983. The Atlantic Barrier Reef ecosystem at Carrie Bow Cay, Belize. Il. Kinorhyncha. - Smithson. Contr. mar. Sci. 18, 1-131.

Kirsteuer, E., 1976. Notes on adult morphology and larval development of Tubiluchus corallicola (Priapulida), based on in vivo and scanning electron microscopic examinations of specimens from Bermuda. - Zool. Scrip. 5, 239-255.

Kirsteuer, E. \& Rützler, K., 1973. Additional notes on Tubiluchus corallicola (Priapulida), based on scanning electron microscope observations. - Mar. Biol. 20, 78-87.

Land, J. van der, 1970. Systematics, zoogeography, and ecology of the Priapulida. - Zool. Verh., Leiden 112, 1-118.

Land, J. van der, 1975. Priapulida. In: Reproduction of marine invertebrates. Ed. by A. C. Giese \& J. S. Pearse. Acad. Press, New York, 2, 55-65.

Lang, K., 1948. On the morphology of the larva of Priapulus caudatus Lam. - Ark. Zool. 41A, 1-12.

Mattisson, A., Nilsson, S. \& Fänge, R., 1974. Light microscopical and ultrastructural organization of muscles of Priapulus caudatus (Priapulida) and their responses to drugs, with phylogenetic remarks. - Zool. Scr. 3, 209-218.

Moritz, K., 1972. Zur Feinstruktur integumentaler Bildungen bei Priapuliden (Halicryptus spinulosus und Priapulus caudatus). - Z. Morph. Ökol. Tiere 72, 203-230.

Purasjoki, K. J., 1944. Beiträge zur Kenntnis der Entwicklung und Ökologie der Halicryptus spinulosus-Larve (Priapulida). - Annls zool. Soc. zool. bot. fenn. 9, 1-14.

Rehkämper, G., Storch, V., Alberti, G. \& Welsch, U., 1989. On the fine structure of the nervous system of Tubiluchus philippinensis (Tubiluchidae, Priapulida). - Acta zool., Stockh. 70 (in press.)

Storch, V. \& Alberti, G., 1985. Ultrastructural investigation of the integument of Tubiluchus philippinensis (Priapulida, Tubiluchidae). - Zool. Scr. 14, 265-272.

Storch, V., Higgins, R. P. \& Morse, M. P., 1989. The internal anatomy of Meiopriapulus fijiensis. Trans. Am. microsc. Soc. (In press.) 